\title{
EMBRIOGÊNESE SOMÁTICA IN VITRO DE CULTIVARES DE CENOURA (1)
}

\author{
BENEDITA MARIA RODRIGUES $(2,4)$, WALTER JOSÉ SIQUEIRA $(2,4)$, \\ JOĀO BAPTISTA FORNASIER $(3,4)$, ROGÉRIO SALLES LISBĀO $(3,4)$ \\ E HERCULANO PENNA MEDINA FILHO $(2,4)$
}

\begin{abstract}
RESUMO
Objetivando a definição da metodologia básica para a obtenção em meio de cultura sólido de embriogênese somática, em explantes de hipocótilo e folha cotiledonar de cenoura (Daucus carota L.) cultivares Kuroda, Nantes e Brasilia foi realizado um experimento em condiçōes de laboratório, utilizando-se as concentrações de 0,$5 ; 1,0 ; 2,5$ e 5,0 mg/litro do ácido 2,4 diclorofenoxiacético $(2,4-D)$ e $1,0 \mathrm{mg} /$ litro do ácido $\beta$-naftoxiacético (NOA). Pelos resultados obtidos, os explantes de hipocótilo foram em geral mais adequados para o desenvolvimento do processo de embriogênese somática nos três cultivares estudados. A melhor concentração de 2,4-D na indução da embriogênese foi de $0,5 \mathrm{mg} /$ litro. $O$ tratamento com o NOA apresentou maior freqüência de embriogênese comparativamente àqueles com o 2,4-D. Houve uma resposta diferencial dos cultivares e explantes utilizados em relação aos diferentes meios de cultura.
\end{abstract}

Termos de indexaçāo: cenoura, Daucus carota L., embriogênese somática, meios de cultura e tipos de explantes.

(1) Trabalho apresentado no 1 Encontro da Associaçāo Brasileira de Cultura de Tecidos de Planta (ABCTP), em Botucatu, SP, em 26 de setembro de 1985. Recebido para publicação em 25 de novembro de 1986.

(2) Seção de Genética, Instituto Agronômico (IAC), Caixa Postal 28, 13001 Campinas (SP).

(3) Seção de Hortaliças Diversas, IAC.

(4) Com bolsa de pesquisa do CNPq. 


\section{INTRODUÇĀO}

A cenoura ocupa uma posição de destaque entre as hortaliças comercializadas pelas principais centrais de abastecimento do Pais, sendo produzida em larga escala nos Estados de São Paulo, Minas Gerais e Paraná. Além da importância econômica, apresenta também maior valor nutritivo entre as hortaliças de raiz; por isso, é preferencialmente incluída na dieta alimentar de crianças na forma "in natura" ou após o processamento industrial.

Seu cuitivo é realizado no outono-inverno, utilizando-se o cultivar Nantes, de excelente qualidade comercial. Por outro lado, vem crescendo em importância o cultivo de primavera-verăo, pelo desenvolvimento dos cultivares Brasília e Kuronan, de aspecto comercial superior ao do cultivar Kuroda, tradicionalmente empregado nessa época. No entanto, 'Brasília' e 'Kuronan' ainda apresentam qualidades agronômicas e comerciais inferiores às do 'Nantes', apesar de possuirem resistência à queima das folhas (Aiternaria dauci) e elevado potencial produtivo.

A cultura de tecidos, por sua vez, pode ser adotada como uma técnica auxiliar no melhoramento genético da cenoura, através da análise da variabilidade comumente apresentada pelas plantas regeneradas a partir de calos. A ocorrência e a origem dessa variabilidade, recentemente denominada de variação somaclonal, têm sido objeto de estudos por pesquisadores em várias espécies vegetais (LARKIN \& SCOWCROFT, 1981, 1983; OONO, 1983; EVANS et al., 1984; ILLG \& SIQUEIRA, 1984, e MARX, 1984).

Entretanto, para que a exploração da variação somaclonal seja viável em melhoramento genético, torna-se necessário o desenvolvimento prévio de metodologia, visando à definição das condições adequadas de cultura in vitro em relação aos cultivares de cenoura comumente plantados em nossas condições.

A formação de plântulas de cenoura a partir de calos foi primeiramente relatada por LEVINE (1950) e WIGGANS (1954). Todavia, em estudos detalhados sobre o processo de regeneração de plântulas, STEWARD et al. (1958) concluíram que a cultura artificial de células de cenoura conduz à formação de plantas somente através de organogênese. Observações posteriores, no entanto, demonstraram a formação de embriões a partir de calos, estabelecendo-se um processo de embriogênese em cenouras, segundo Reinert, citädo por HALPERIN \& WETHERELL, 1964. Esses mesmos autores obtiveram alta freqüência de formação de embriôes, a partir de calos derivados de raízes, peciolos ou pedúnculos da umbeleta de cenoura selvagem a partir de meio básico constituido de sais minerais, vitaminas e sacarose suplementado com adenina e ácido 2,4-diclorofenoxiacético $(2,4-D)$. Observaram também alta heterogeneidade morfogenética nos calos desenvolvidos em meio contendo água de coco imaturo e 2,4-D ou cinetina e 2,4-D. 
BAYLLISS (1977), trabalhando com a cultura liquida de células de cenoura, observou existirem interferências do 2,4-D nos estádios da mitose dessas células, desde bloqueio ou atraso nas fases $G_{1}$ ou $G_{2}$, associado com a deposição de lignina, até alterações na formação e função dos fusos mitóticos.

KAMADA \& HARADA (1979) investigaram o efeito de auxinas e citocininas em diferentes concentraçōes, sobre a embriogênese somática e formação de raizes, a partir de segmentos de hipocótilo obtidos pela esterilizaçăo de plântulas de uma semana de idade do cultivar US-Harumakigosun. Relataram a indução de ralzes e de embriōes somáticos em baixas e altas concentrações das auxinas ácido 3-indolacético, ácido $\beta$-naftoxiacético, ácido indolbutírico e ácido L-naftalenoacético. Constataram os mesmos a inibição da organogênese nos meios de cultura contendo as citocininas 6-benziladenina, zeatina ou $\mathrm{N}$-fenil- $\mathrm{N}$ ':-(4-piridyl) uréia.

RONCHI et al. (1984), trabalhando com explantes de hipocótilo da variedade de cenoura $\mathrm{S}$. Valery, verificaram o efeito marcante dos aminoácidos prolina e serina no aumento de divisōes mitóticas e produção de embriōes no meio de cultura contendo 2,4-D em diversas concentrações.

No Brasil, poucos são os trabalhos sobre a cultura de tecidos em cenoura. Neste sentido, salienta-se o estudo conduzido por FAZIO (1975) sobre a cultura sólida de segmentos do parênquima de floema de raiz onde se observaram aspectos ultra-estruturais dos calos. MANETTI FILHO (1981) estudou em cultura de células em suspensão a tolerância de oito cultivares de cenoura a niveis elevados de manganês $(0,1$ a $32,0 \mu \mathrm{M})$. SOUSA \& TORRES (1982) obtiveram a formação de tecidos não organizados ou calos em todos os tratamentos envolvendo quatro concentraçōes de 6-benziladenina, ocorrendo a obtenção de plântulas somente aos 127 dias desde o início da cultura dos explantes.

O presente trabalho teve por objetivo a definiçáo da metodologia básica para a obtenção de plântulas em meio de cultura sólido, a partir da embriogênese somática em dois tipos de explantes de cultivares comerciais de cenoura. Esse estudo servirá de base para a análise e identificação de genótipos superiores de mutantes de cenoura obtidos entre as inúmeras plantas regeneradas.

\section{MATERIAL E MÉTODOS}

As sementes de cenoura dos cultivares Nantes, Brasília e Kuroda foram fornecidas pela Seção de Hortaliças Diversas, Instituto Agronômico.

Foi realizada a esterilização superficial do tegumento das sementes a partir da pré-incubação das mesmas por cerca de 17 horas em placas de Petri contendo papel de filtro levemente umedecido com água monodestilada. Depois desse período, as sementes foram imersas por um minuto em álcool-anidro diluído a $50 \%$ e permaneceram durante 30 minutos sob agitação, em solução de hipoclo- 
rito de sódio a 2,5\% adicionado de oito gotas por litro de Tween 20. Foram a seguir lavadas cinco vezes em água esterilizada e colocadas em papel de filtro esterilizado, para absorção do excesso de umidade. Dessa maneira, as sementes foram transteridas, assepticamente, para frascos de $150 \mathrm{ml}$ contendo $30 \mathrm{ml}$ da solução inorgânica de HOAGLAND \& SNYDES (1934), acrescida de $8 \mathrm{~g} /$ /litro de bacto-ágar, em pH 5,5. Essa metodologia, empregada para a esterilização e germinação asséptica das sementes, foi baseada em HALPERIN \& WETHERELL (1964), com algumas modificaçőes.

Inocularam-se cinco a oito sementes por frasco, que foi inicialmente mantido em ausência de luz até a emergência da radícula. Posteriormente, os frascos foram transferidos para câmara de crescimento ajustada para fotoperíodo de 12 horas de luz ( 2.000 a 2.500 Lux) e temperatura de 18 a 22 ${ }^{\circ} \mathrm{C}$, necessários ao desenvolvimento das plântulas dos cultivares empregados. Aos 30 dias, aproximadamente, as plântulas sem contaminação aparente foram utilizadas para a obtenção em condiçōes assépticas dos segmentos de hipocótilo e de folha cotiledonar (explantes) de $5 \mathrm{~mm}$ de comprimento, e usados para as inoculações nos diferentes meios de cultura. A composição básica dos meios de cultura constituia-se de sais minerais de MURASHIGE \& SKOOG (1962), enriquecido com os seguintes componentes orgânicos em miligramas/litro: myo-inositol (100); glicina (2); ácido nicotínico (5); piridoxina $\mathrm{HCL}(0,5)$; tiamina $\operatorname{HCL}(0,5)$; ácido fólico $(0,5)$; biotina $(0,05)$; sacarose $(20.000)$ e bacto-ágar $(8.000)$. $\mathrm{O} \mathrm{pH}$ dos meios de cultura foi ajustado para 5,5 .

A partir desse meio básico, foram definidos os meios de cultura primários para a indução de calos e de embriocênese somática. Utilizaram-se como fitorreguladores 0 ácido 2,4-diclorofenoxiacético (2,4-D), nas concentrações de 0,5; 1,$0 ; 2,5$ e $5,0 \mathrm{mg} /$ litro, e o ácido $\beta$-naftoxiacético (NOA) a $1,0 \mathrm{mg} / \mathrm{litro}$, os quais constituiram os tratamentos $A, B, C, D$ e $E$ respectivamente. $O \mathrm{pH}$ dos meios de cultura primários foi ajustado para 5,5 antes da adição do ágar e, em seguida, autoclavou-se em temperatura de $120^{\circ} \mathrm{C}$, a uma atmosfera de pressão, durante 20 minutos. Para cada tratamento, foram inoculados separadamente três explantes de hipocótilo e de folha cotiledonar dos cultivares Nantes, Brasllia e Kuroda, em frascos de $50 \mathrm{ml}$ contendo $10 \mathrm{ml}$ de meio de cultura. O número de cada tipo de explante, para cada concentração e cultivar, variou ao redor de 30 , em razão da eliminação dos frascos que apresentaram contaminação após o tempo de cultura primária. Os tratamentos foram dispostos ao acaso em prateleiras com iluminação artificial de 2.000 a 2.500 lux, em fotoperiodo de 16 horas de luz e temperatura de 25 a $28^{\circ} \mathrm{C}$. Os explantes dos tratamentos com o 2,4-D ( $A, B, C$ e D), depois de 18 dias de cultura primária, foram transferidos para o mesmo meio básico sem fitorreguladores, para que se estabelecesse definitivamente o processo de morfogênese somática. Esse periodo foi ligeiramente superior ao adotado por KAMADA \& HARADA (1979). O mesmo procedimento foi realizado para o tratamento $\mathrm{E}$ ( $1 \mathrm{mg} / \mathrm{litro}$ de NOA), após 35 dias em meio primário, de acordo com as indicações de KAMADA \& HARADA (1979). As condições ambientais de manu- 
tenção das culturas secundárias e $\mathrm{opH}$ foram semelhantes ao realizado para a cultura inicial dos explantes. Decorridos 60 dias desde a cultura primária, realizaram-se as avaliaçōes, atribuindo-se uma escala de notas de 0 a 6 , de acordo com o desenvolvimento e com a fase apresentada pelo explante individualmente.

Com base nessa avaliação, foi obtida a distribuição em porcentagem dos explantes nas sete diferentes notas, para cada tipo de explante, meio de cultura e cultivares utilizados. A terminologia adotada foi a de KAMADA \& HARADA (1979), ao nos referirmos às formações embrionárias nos calos.

A escala de notas obedeceu ao seguinte critério:

0: Explante sem o desenvolvimento inicial aparente de calo;

1: Explante com início de desenvolvimento de calo, sem a ocorrência simultânea de embriogênese, notando-se ainda a superficie original do explante;

2: Calo mais desenvolvido, envolvendo, praticamente, toda a superficie do explante, mas sem apresentar tecido embriogênico aparente;

3: Explante com inicio de desenvolvimento de calo embriogênico;

4: Toda a superfície do explante apresenta calo embriogênico com predominância de embriōes globulares;

5: Calo embriogênico mais desenvolvido, com a formação de embriōes somáticos em vários estádios de desenvolvimento (globular, coração, torpedo e cotiledonar), com alguns setores esverdeados;

6: Maior individualização dos embriōes, plântulas em desenvolvimento, maior acúmulo de tecidos clorofilados.

Dentro dessa escala, percebe-se que, nas classes de 0 a 2, tem-se apenas a indução e crescimento de calos; a partir daị, vários estádios do processo de embriogênese somática até a ocorrência definitiva de plântulas (Figura 1).

Os embriôes bem individualizados e as plântulas já formadas foram transferidos (cerca de quatro por frasco) para o mesmo meio de cultura sem fitorregulador (meio secundário), para completar o desenvolvimento da parte aérea e das raizes.

\section{RESULTADOS E DISCUSSÃO}

A taxa de germinação das sementes dos cultivares variou de 80 a $90 \%$, enquanto a contaminação esteve ao redor de 5 a $10 \%$, sendo considerada baixa. Esse fato mostra que a metodologia adotada para esterilização e germinação in vitro das sementes, para posterior utilização das plântulas na obtenção dos explantes, foi satisfatória. Dessa maneira, evitaram-se os inconvenientes da oxidação e de outras injúrias geralmente apresentados pelos explantes, cujas plântulas ou partes delas são submetidas ao tratamento de esterilização, como o realizado por KAMADA \& HARADA (1979). 

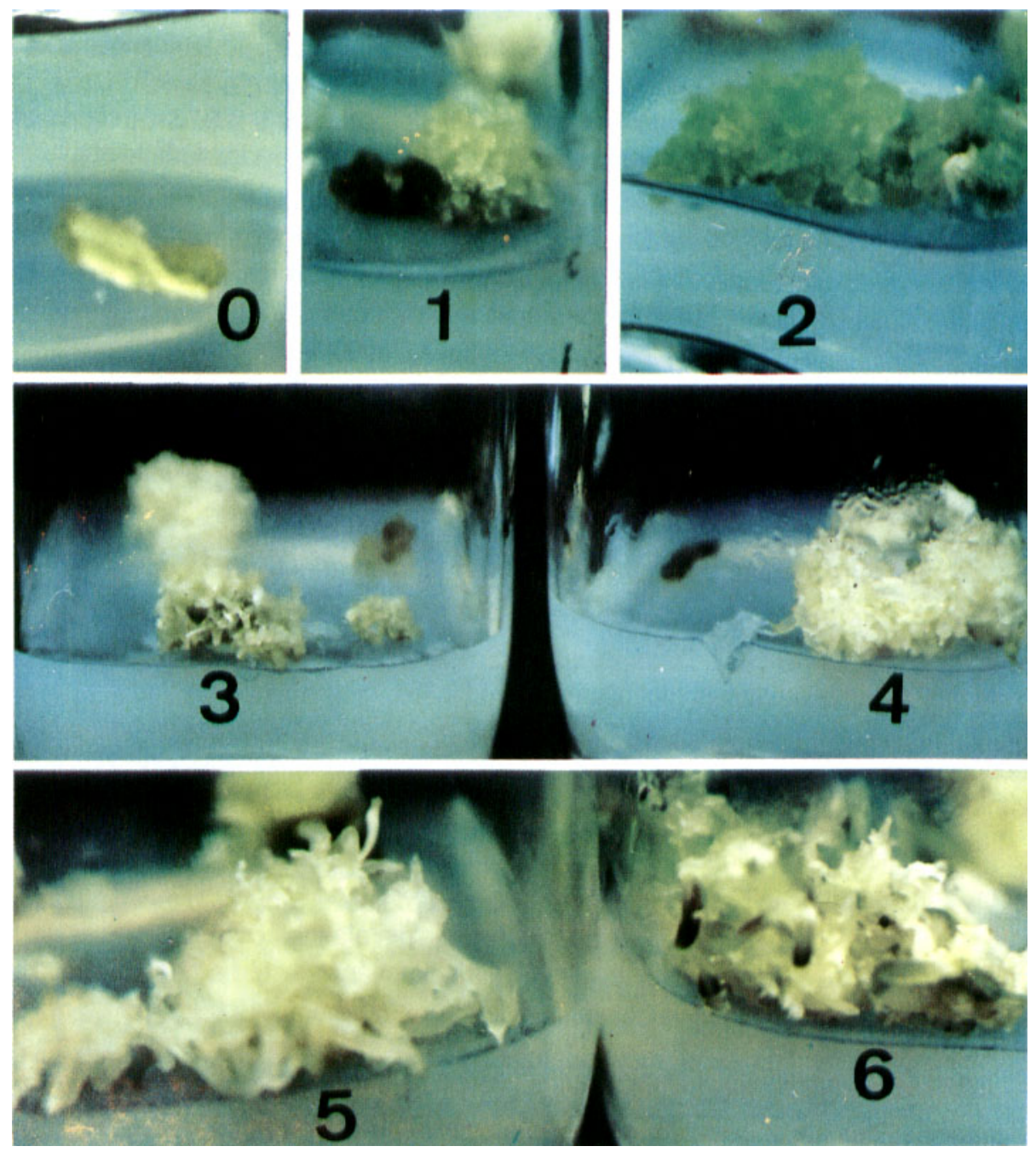

FIGURA 1. Escala de notas de 0 a 6, atribuidas aos explantes (hipocótilo ou folha cotiledonar), de acordo com o estádio de desenvolvimento dos calos ou da embriogênese somática.

Nas figuras 2 e 3 estão representadas as distribuições das porcentagens obtidas nas diferentes notas para os tratamentos com, respectivamente, 2,4-D e NOA, envolvendo tipo de explante e cultivares de cenoura.

Pela figura 2, observa-se que houve uma redução na porcentagem de explantes apresentando embriogênese (Notas 4,5 e 6 ), à medida que se elevou a concentração de 2,4-D. Essa redução se tornou drástica para os explantes de folha cotiledonar. 


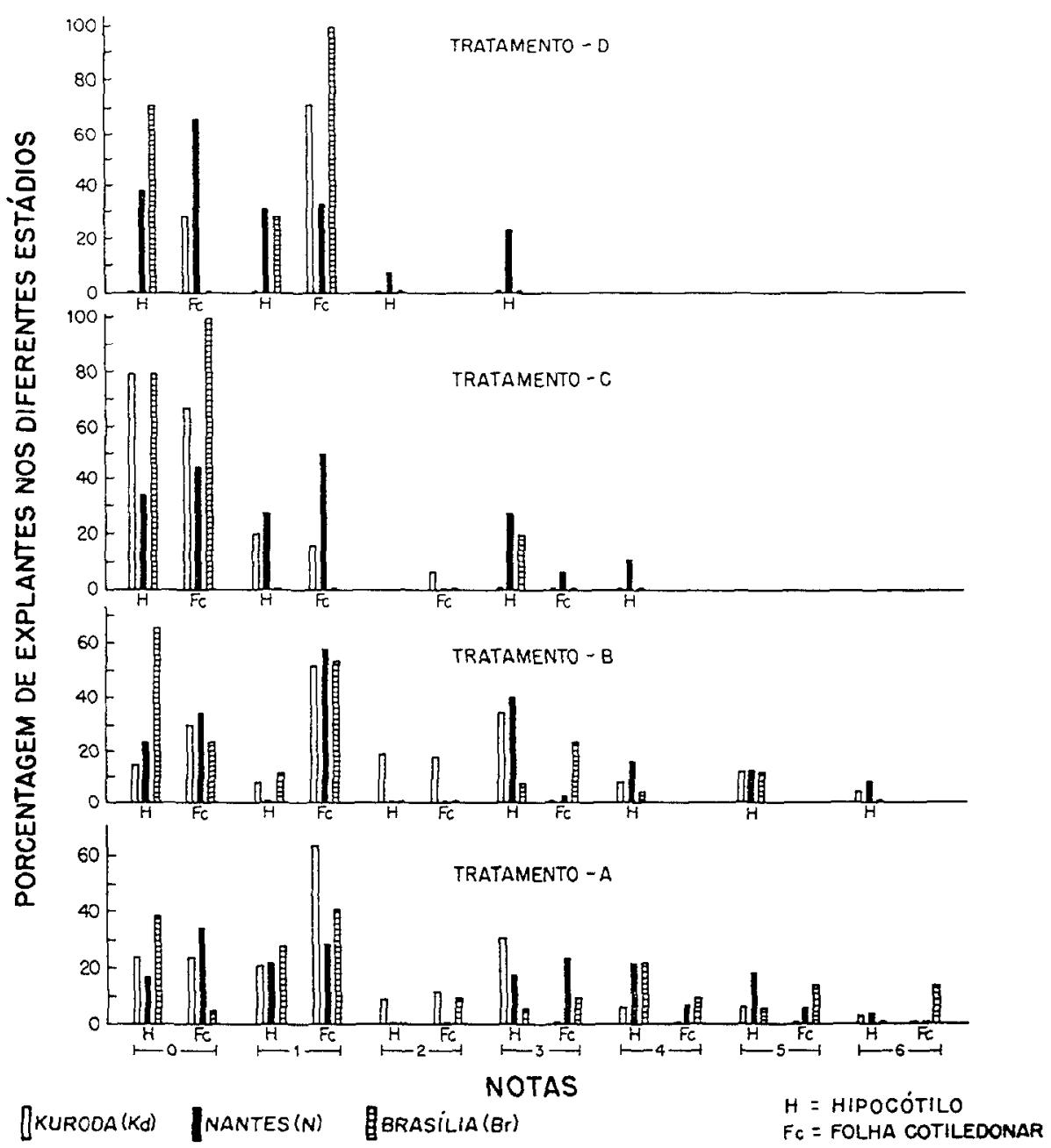

FIGURA 2. Efeito de diferentes concentraçōes de 2,4-D no desenvolvimento da embriogênese somática em três cultivares de cenoura a partir de explantes de hipocótilo $(\mathrm{H}) \mathrm{e}$ folha cotiledonar ( $\mathrm{Fc}$ ). Distribuição das porcentagens de explantes nos diferentes estádios, referentes às sete notas.

Entretanto, mesmo no tratamento com a menor concentração de 2,4-D, ocorreram muitos explantes nas notas 0,1 e 2 , onde se verificou ausência ou formação de calo näo-embriogênico.

Portanto, o elevado número de explantes dos três cultivares que não desenvolveram calo (nota 0 ) sugere algum efeito deletério nos seus tecidos ou 
células, principalmente nas concentrações de 2,4-D acima de 0,5 mg/litro, e após o tempo de cultura inicial de 18 dias na presença desse fitorregulador, a exemplo do que foi encontrado por BAYLLISS (1977), trabalhando com a cultura líquida de células em suspensão.

O tratamento com NOA (Figura 3) foi superior àqueles com 2,4-D, pela maior distribuição dos explantes nas notas 3, 4, 5 e 6 . Esse resultado está de acordo com o de KAMADA \& HARADA (1979), que utilizaram segmentos de hipocótilo do cultivar US-Harımakigosun. O 'Nantes' foi o único que na concentração de $5 \mathrm{mg} /$ /itro de 2,4-D apresentou calo embriogênico (23,0\% com nota 3). O número de explantes com a formação de calos embriogênicos desse cultivar aumentou gradativamente com o decréscimo da concentração de 2,4-D, principalmente para o explante de hipocótilo. $O$ 'Brasília' apresentou embriogênese para explante de hipocótilo na concentração de 2,5 mg/litro para o 2,4rD (tratamento C) e para folha cotiledonar nas concentrações inferiores desse fitorregulador (tratamentos $\mathrm{A}$ e B). Vale ressaltar, também, que esse cultivar foi o único que apresentou explantes de folha cotiledonar (13,5\%) com embriogênese no estádio representado pela nota 6 , no tratamento com $0,5 \mathrm{mg} / \mathrm{litro}$ de 2,4-D. Por sua vez, o 'Kuroda' não apresentou explantes de folha cotiledonar com embriogê nese somática em nenhuma das concentraçōes de 2,4-D. Para esse fitorregulador, a embriogênese somática somente foi constatada, nesse cultivar, em explantes de hipocótilo submetidos às menores concentraçóes de 2,4-D (tratamentos $\mathrm{A}$ e B). Houve, portanto, um comportamento diferencial para os três cultivares de cenoura estudados, entre as quatro concentraçōes de 2,4-D e para os dois tipos de explantes utilizados.

A ocorrência de embriogênese do cultivar Nantes nos explantes de hipocótilo, também em elevada concentração de 2,4-D $(5 \mathrm{mg} /$ /itro), pode favorecer o aumento de freqüência de plantas mutantes regeneradas, a exemplo do que foi constatado em outras espécies (NOVAK, 1974, 1980).

Analisando-se as diferentes concentraçōes de 2,4-D, verificou-se que, em geral, o explante de hipocótilo se mostrou mais adequado ao desenvolvimento do processo de embriogênese nos três cultivares de cenoura.

Observou-se a superioridade do ácido $\beta$-naftoxiacético (NOA) na indução de embriogênese em relação ao 2,4-D para qualquer tipo de explante e cultivar. Para o tratamento com NOÁ, o somatório das porcentagens individuais obtidas nas notas 4,5 e 6, que refletem os estádios mais avançados da embriogênese somática, apresentou os seguintes valores, respectivamente para hipocótilo e folha cotiledonar. 'Kuroda', 49,5 e 75,0\%; 'Nantes', 64,5 e 15,0\%, e 'Brasília', 55,5 e $70,0 \%$. Para esse fitorregulador, portanto, as respostas foram satisfatórias para os dois tipos de explantes nos cultivares Kuroda e Brasília; para o 'Nantes', porém, o explante de hipocótilo se mostrou bastante superior, quanto ao desenvolvimento da embriogênese somática. 


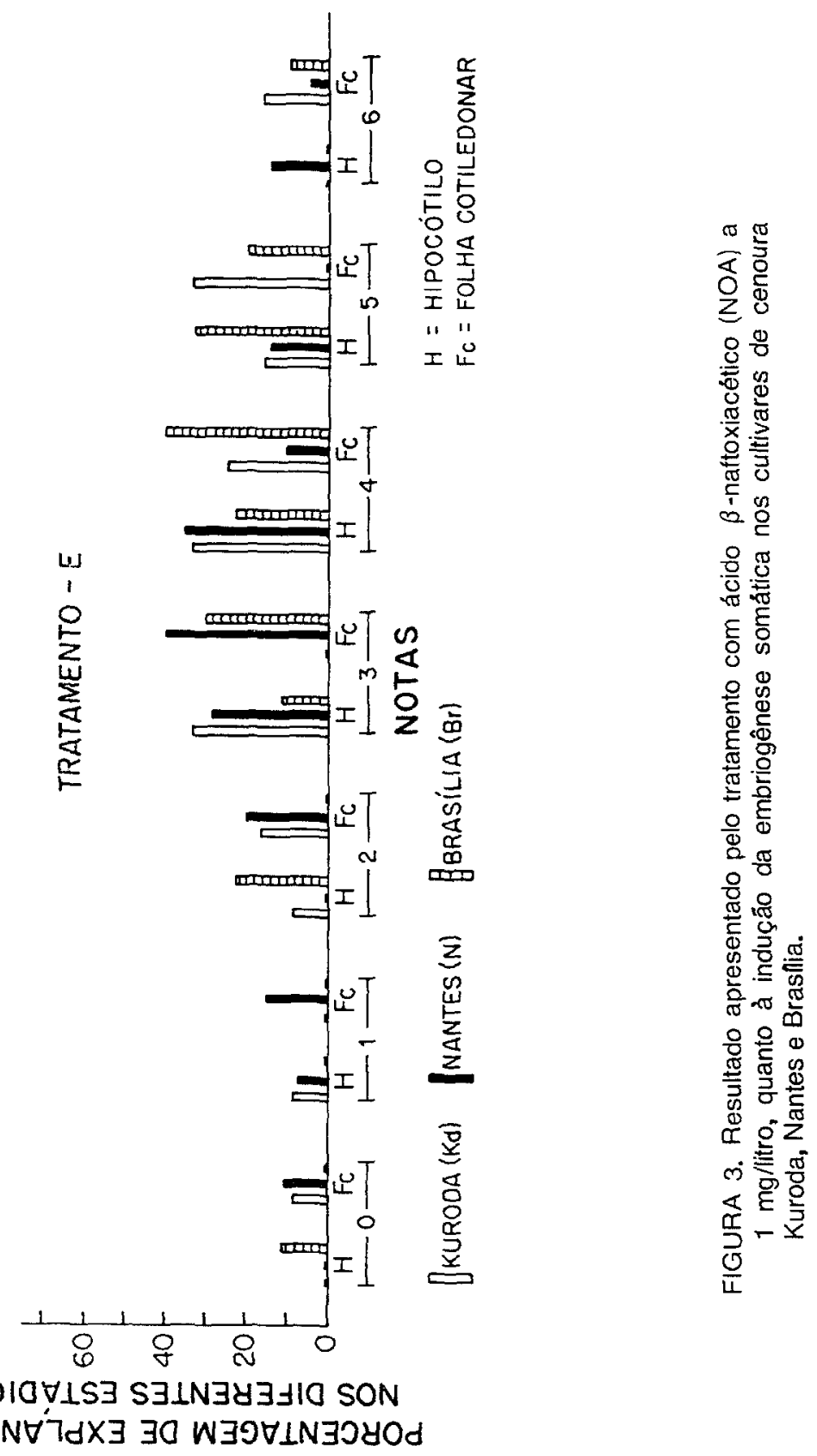


Analisando-se somente a concentração de 2,4-D a 0,5 mg/litro, têm-se os seguintes valores para hipocótilo e folha cotiledonar, respectivamente, após o somatório das porcentagens das três últimas notas: 'Kuroda', 15,0 e 0,0\%; 'Nantes', 43,5 e 13,0\%, e 'Brasília', 27,5 e 36,0\%. Dessa maneira, verificou-se que apenas no cultivar Braślia o explante de folha cotiledonar foi superior ao do hipocótilo.

A embriogênese seguida da individualização e obtenção de plântulas foi conseguida, portanto, para os três cultivares nos dois tipos de explantes, nos meios de cultura envolvendo o NOA (1 mg/litro) e 2,4-D a 0,5 mg/litro (exceção para folha cotiledonar do 'Kuroda'), após 60 dias de cultura, ou seja, praticamente na metade do tempo obtido por SOUZA \& TORRES (1982). Estudos devem ser realizados, utilizando-se concentrações inferiores de 2,4-D a partir de 0,5 mg/litro ou reduzindo-se o tempo de permanência dos explantes na cultura primária, visto que, nas condições do presente trabalho, houve aumento da freqüência de embriogênese, com o decréscimo da concentração desse fitorregulador. Em razão da possibilidade de exploração da variação somaclonal nesses cultivares de cenoura, é de interesse a utilização do 2,4-D pela sua comprovada ação mutagênica, durante os processos de indução e crescimento de calos (NOVAK, 1974, e BAYLLISS, 1977). O desempenho do NOA na indução da embriogênese somática nos três cultivares estudados também possibilita a seleção posterior de possiveis variantes somaclonais para o melhoramento genético dessa importante hortaliça.

\section{CONCLUSÕES}

Os resultados obtidos permitem concluir que:

1) A metodologia utilizada para a esterilização e germinação in vitro das sementes dos cultivares de cenoura Kuroda, Nantes e Brasília foi satisfatória;

2) Nos tratamentos envolvendo o 2,4-D, os explantes de hipocótilo foram mais adequados do que os de folha cotiledonar, no estabelecimento do processo in vitro de embriogênese somática, nos cultivares de cenoura estudados;

3) $O$ tratamento com o ácido $\beta$-naftoxiacético (NOA) a $1 \mathrm{mg} /$ litro, foi superior àqueles contendo $\Theta$ ácido 2,4-diclorofenoxiacético (2,4-D), para qualquer tipo de explante e cultivar utilizado;

4) Dentre as concentrações de 2,4-D testadas, a de $0,5 \mathrm{mg} /$ litro foi a mais eficiente na indução da embriogênese em comparação com as demais concentrações desse fitorregulador;

5) O cultivar Nantes foi o único que apresentou embriogênese no tratamento mais elevado de 2,4-D (5 mg/litro), somente para o explante de hipocótilo (23,0\% com nota 3$)$; 
6) O 'Brasília', por sua vez, apresentou $13,5 \%$ de embriogênese em folha cotiledonar, no estádio máximo (nota 6), enquanto 'Kuroda' praticamente não exibiu embriogênese em nenhuma das concentrações de 2,4-D envolvendo folha cotiledonar;

7) Para a indução e desenvolvimento da embriogênese somática, na concentração de $1 \mathrm{mg} / \mathrm{litro}$ de NOA, devem ser utilizados explantes de hiporótilo ou folha cotiledonar para os cultivares Kuroda e Brasília e explantes de hipocótilo para o 'Nantes'. Quanto ao 2,4-D a 0,5 mg/litro, para os cultivares Kuroda e Nantes, são indicados os explantes de hipocótilo e, para o 'Brasília', os dois tipos são adequados.

\section{SUMMARY}

\section{SOMATIC EMBRYOGENESIS IN VITRO FROM CARROT CULTIVARS}

An investigation was conducted under laboratory conditions, to define the basic methodology in solid culture, to achieve somatic embryogenesis in tissue of hypocotyl and cotyledon of carrot (Daucus carota L.) cultivars Kuroda, Nantes and Braslia. Different concentrations of 2,4-D (0.5; $1.0 ; 2.5$ and $5.0 \mathrm{mg} / \mathrm{l}$ ) were studied in comparison to $1.0 \mathrm{mg} / \mathrm{l}$ of NOA. The results showed that the hypocotyl explants of the three cultivars were more adequate to develop somatic embryogenesis than the cotyledonary tissues. The best concentration of 2,4-D for inducting embryogenesis was $0.5 \mathrm{mg} / \mathrm{l}$, independently of the kind of explant and cultivar. However it was less efficient than NOA at $1.0 \mathrm{mg} /$. It was also observed that the carrot cultivars and the explants studied, reacted differently to the tissue culture medium utilized.

Index terms: carrot, Daucus carota L., somatic embryogenesis, culture media, explants.

\section{REFERÉNCIAS BIBLIOGRÁFICAS}

BAYLLISS, M.W. The effects of 2,4-D on growth and mitosis in suspension cultures of Daucus carota. Plant Science Letters, 8:99-103, 1977.

EVANS, D.A.; SHARP, W.R. \& MEDINA FILHO, H.P. Somaclonal and gametoclonal variation. American Journal of Botany, 71(6):759-774, 1984.

FAZIO, G.M. de. Aspectos ultra-estruturais de "callus" de raiz de cenoura (Daucus carota L.) cultivados em meio de cultura sólido e em condições de luz e temperatura ambientes. Arquivos do Instituto Biológico, São Paulo, 42:9-16, 1975.

HALPERIN, W. \& WETHERELL, D.F. Adventive embryony in tissue cultures of the wild carrot, Daucus carota. American Journal of Botany, 51(3):274-283, 1964.

HOAGLAND, D.R. \& SNYDES, W.C. Nutrition of strawberry plant under controlled conditions: (A) Effects of boron and certain other elements; (B) Susceptibility to injury to sodium salts. Proceedings of the American Society for Horticultural Science, 30:288-294, 1934. 
ILLG, R.D. \& SIQUEIRA, W.J. Variabilidade genética induzida atravês da cultura de tecidos. In: COLÓQUIO DE CITOGENÉTICA E EVOLUÇÃO DE PLANTAS, 1., Piracicaba, 1984. p.125-135.

KAMADA, H. \& HARADA, $H$. Studies on the organogenesis in carrot tissue cultures. I. Effects of growth regulators on somatic embryogenesis and root formation. Zeitschrift fuer Pflanzen-Physiologie, Bd. 91(3):255-266, 1979.

LARKIN, P.J. \& SCOWCROFT, W.R. Somaclonal variation: a novel source of variability from cell cultures frorn plant improvement. Theoretical and Applied Genetics, 60:197-214, 1981.

\& - Somacional variation and crop improvement. In: GENETIC engineering of plants and agricultural perspective. New York, Plenum Press, 1983. p.289314.

LEVINE, M. The growth of normal plant tissue "in vitro" as affected by chemical carcinogens and plant growih substances. I. The culture of the carrot taproot meristem. American Journal of Botany, 37:445-458, 1950.

MANETTI FILHO, J. Tolerância de tecidos de cenoura (Daucus carota L.) a niveis elevados de manganês. Indução e seleção. Campinas, UNICAMP, 1981. 97p. Tese (Mestrado)

MARX, J.L. Instability in plants and the ghost of Lamark. Science, 224:1415-1416, 1984.

MURASHIGE, T. \& SKOOG, F. A revised medium for rapid growth and bioassays with tobacco tissue culture. Physiologia Plantarum, 15:473-497, 1962.

NOVAK, F.J. The change of kariotype in callus cultures of Allium sativum L. Caryologia, 27:45-54, 1974.

Phenotype and cytological status of plants regenerated from callus cultures of Allium sativum L. Zeitschrift fuer Pflanzenzüchtung, 84:250-260, 1980.

OONO, K. Genetic variability in rice plants regenerated from cell cultures. In: CELL AND TISSUE CULTURES TECHNIQUES FOR CEREAL CROP IMPROVEMENT. Proceedings. New York, Gordon and Breach Science Publ., 1983. p.95-104.

RONCHI, V.N.; CALIGO, M.A.; NOZZOLINI, M. \& LUCCARINI, G. Stimulation of carrot somatic embriogenesis by proline and serine. Plant Cell Reports, 3:210-214, 1984.

SOUZA, E.L.S. \& TORRES, A.C. Propagaçăo vegetativa da cenoura. In: CONGRESSO BRASILEIRO DE OLERICULTURA, 22, Vitória, 1982. Resumos. p.146.

STEWARD, F.C.; MAPES, M.O. \& MEARS, K. Growth and organized development of cultured cells. Il. Organization in cultures grown from freely suspended cells. American Journal of Botany, 45:705-708, 1958.

WIGGANS, S.C. Growth and organ formation in callus tissues derived from Daucus carota. American Journal of Botany, 41:321-326, 1954. 